
ВПЛИВОМ ІНТЕРЛЕЙКІНУ-2 В УМОВАХ ФІЗИЧНИХ ТРЕНУВАНЬ

\section{Рівень кортизолу та динаміка поведінкових реакцій у мишей під впливом інтерлейкіну-2 в умовах фрізичних тренувань}

\section{В. А. Швець, О. М. Гасюк}

Херсонський державний університет

Резюме. Реакція гіпоталамо-гіпофрізарно-наднирковозалозної системи, що супроводжується збільщенням в крові кортизолу, адекватно величині фрізичного навантаження, може слугувати важливим раннім індикатором перетренування і виникнення стресу. Стрес, у свою чергу, призводить до значних змін у чентральній нервовій системі, що яскраво проявляється у поведінкових реакціях. Інтерлейкін-2 (ІЛ-2) може чинити одночасний вплив на регулювання гомеостазу в мозку та в імунній системі. ІЛ-2 ефективно використовується при лікуванні імуносупресії, викликаної стресом, і володіє стимулювальним та антидепресивним ефектами.

Мета дослідження - оцінити вплив ІЛ-2 на рівень кортизолу та динаміку поведінкових реакцій у мишей при орізичному стресі.

Матеріали і методи. Дослідження проводили на статевозрілих лабораторних мишах-самцях. Було сорормовано п'ять дослідних та одну контрольну (без фрізичних тренувань) групи тварин. Перша група отримувала інгібітор ІЛ-2 («Циклоспорин») (10 мг/кг), друга, третя та четверта групи - ІЛ-2 («Ронколейкін») у кончентраціях 5000; 7500 та 30000 МО/кг відповідно, п'ята група-стерильний фрізіологічний розчин. У якості фрізичного тренування використовувався метод примусового плавання до повного виснаження з вантажем. Вміст кортизолу в сироватиі крові визначали з використанням реагентів «Кортизол - ІФА». Поведінку тварин досліджували, використовуючи методику «відкрите поле».

Результати. Стимуляція ІЛ-2 у високій концентрації призвела до суттєвого збільшення рівня кортизолу в сироватці крові мишей на 4-му та 6-му тижнях порівняно 3 контролем та попереднім періодом $(p \leq 0,05)$. Тварини, яким вводили ІЛ-2 в середній концентрації, мали помірне збільшення рівня кортизолу, який зростав протягом усіх фраз адаптації до фрізичного навантаження. Спостерігались достовірні відмінності порівняно з контролем (відповідно на 51,8 \% - на 4-му, на 36,5 \% - на 6-му тижнях,

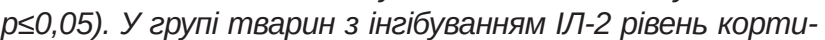
золу на 4-му тижні знизився порівняно з попереднім пері-

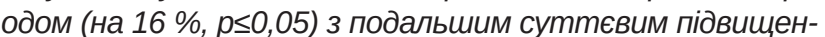

Cortisol level and dynamics of behavioral reactions in mice under the influence of interleukin-2 during physical training V. A. Shvets, O. M. Hasiuk Kherson State University

e-mail: shvetsvika88@gmail.com

Summary. The reaction of the hypothalamic-pituitaryadrenal system, accompanied by an increase in blood cortisol, adequate to the amount of exercise, can serve as an important early indicator of overtraining and stress. Stress, in turn, leads to significant changes in the central nervous system, which is clearly manifested in behavioral reactions. Interleukin-2 (IL-2) may have a simultaneous effect on the regulation of homeostasis in the brain and immune system. The drug IL-2 is effectively used in the treatment of immunosuppression caused by stress, and has stimulating and antidepressant effects.

The aim of the study - to evaluate the effect of IL-2 on cortisol levels and the dynamics of behavioral responses in mice under physical stress.

Materials and Methods. The study was performed on adult male laboratory mice. Five experimental and one control (without physical training) groups of animals were formed. Group I received an inhibitor of IL-2 (Cyclosporine) (10 mg/kg), groups II, III and IV - IL-2 (Roncoleukin) in concentrations of 5000, 7500 and $30,000 \mathrm{IU} / \mathrm{kg}$, respectively, group $\mathrm{V}$ - sterile saline. The method of forced swimming to complete exhaustion with a load was used as physical training. The content of cortisol in the blood serum was determined using reagents "Cortisol - ELISA". The behavior of animals was studied using the method of "Open field".

Results. Stimulation of $\mathrm{L}-2$ in high concentrations led to a significant increase in serum cortisol levels in mice at 4 and 6 weeks compared to the control and previous period ( $p \leq 0.05)$. Animals administered IL-2 at medium concentrations had a moderate increase in cortisol levels, which increased during all phases of adaptation to exercise. Significant differences were observed compared with the control (respectively, by $51.8 \%$ - at the 4 th, by $36.5 \%-$ at the 6 th week, $p \leq 0.05$ ). In the group of animals with IL-2 inhibition, cortisol levels at week 4 decreased compared to the previous period (by $16 \%$, $p \leq 0.05$ ) with a subsequent significant increase (by $110 \%$, $p \leq 0.05)$. Groups of animals with low-concentration IL-2 stimulation and no drug exposure showed an increase in 


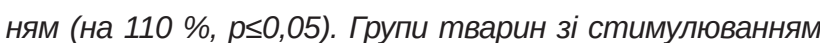
ІЛ-2 в низькій концентрації та без впливу препаратів продемонстрували підвищення рівня кортизолу порівняно з контролем на 4-му тижні та порівняно з попередніми показниками на 6-му тижні фрізичних тренувань. Протягом усіх періодів експерименту була відзначена відмінність показників поведінкової активності в тесті «відкрите поле» залежно від періоду та впливу ІЛ-2 різної концентрації або ж його інгібування.

Висновки. З'ясовано, що уведення ІЛ-2 впливає на концентрацію кортизолу в сироватці крові лабораторних мишей, які знаходились в умовах фрізичних навантажень. У тварин, яким уводили ІЛ-2 в середній концентрації, не було значного підвищення рівня кортизолу. При уведенні малих концентрацій ІЛ-2 рівень кортизолу підвищувався із значним спадом у фразі відновлення. В умовах дії високих концентрацій ІЛ-2 рівень кортизолу підвищувався протягом усіх тижнів, із значним стрибком на останньому тижні орізичних тренувань. Тож середні концентрації ІЛ-2 мають стрес-протекторну дію в умовах фрізичних навантажень. На моделі фрізичного стресу в білих мишей показано, що уведення ІЛ-2 впливає на поведінку дослідних тварин. У середніх концентраціях ІЛ-2 призводить до зниження рівня тривожності, підвищення рухової активності тварин та активізації дослідницької поведінки.

Ключові слова: гормон стресу; поведінкова активність; фрізичне навантаження; адаптація; цитокін.

\section{ВСТУП}

В останні роки все більше привертають увагу дослідження механізмів, що лежать в основі стресової реакції, і чинників, які її регулюють. Стрес впливає на організм неоднозначно, може мобілізувати неспецисрічну адаптивну систему і посилити здатність реагувати, разом з тим, як надмірний стрес може призвести до дисфункціональних реакцій. Проводиться все більше досліджень для з'ясування заходів, необхідних для усунення або ж попередження несприятливих наслідків надмірного стресу. Різноманітні екстремальні чинники, які впливають на організм, запускають компенсаторно-адаптаційні механізми, які відповідним чином змінюють обмін речовин та функціональний стан органів і тканин. До однієї із головних ендокринних ланок, що фрормує адаптації організму у відповідь на зовнішні впливи, відносять активацію симпатоадреналової та гіпоталамо-гіпофізарно-адренокортикальної систем. Так, виконання фрізичних вправ призводить до викиду адренокортикотропного гормону, адреналіну та глюкокортикоїдів, що дозволяє розглядати фрізичне навантаження як один із стресових впливів, який поєднує фрізичний та емоційний компоненти [1-4].

Фізичне навантаження визначається як будь-яка фрізична активність скелетних м'язів, що вимагає витрат енергії. Регулярна фрізична активність - один із кращих способів поліпшити загальний стан здоров'я, знизити ризик діабету, серцево-судинних cortisol levels compared to controls at week 4 and compared to previous values at week 6 of exercise. During all periods of the experiment, there was a difference in behavioral activity in the "Open field" test depending on the period and the effect of IL-2 of different concentrations or its inhibition.

Conclusions. It was found that the introduction of IL-2 affects the concentration of cortisol in the serum of laboratory mice that were exposed to exercise. Animals administered IL-2 at medium concentrations did not have a significant increase in cortisol levels. At low concentrations of IL-2, cortisol levels increased with a significant decrease in the recovery phase. Under conditions of high concentrations of IL-2, cortisol levels increased during all weeks, with a significant jump in the last week of exercise. Therefore, average concentrations of $I L-2$ have a stress-protective effect under exercise. In a model of physical stress in white mice, it was shown that the introduction of IL-2 affects the behavior of experimental animals. At medium concentrations, IL-2 leads to a decrease in anxiety, increased motor activity of animals and increased research behavior.

Key words: stress hormone; behavioral activity; physical activity; adaptation; cytokine.

захворювань та депресії. Вправи можуть спричинити і гормональні зміни, наприклад підвищення рівня кортизолу [5-6]. Реакція гіпоталамо-гіпофрізарнонаднирковозалозної системи, що супроводжується збільшенням у крові кортизолу, адекватна величині фрізичного навантаження, може слугувати важливим раннім індикатором перетренування і виникнення стресу [7]. Стрес, у свою чергу, призводить до значних змін в центральній нервовій системі, що яскраво проявляється у поведінкових реакціях [8]. 3 боку імунної системи ці зміни описують як опосередковану імуносупресію після фрізичних тренувань [6, 9].

Розвиток клітинної або гуморальної імунної відповіді буде залежати від репертуару цитокінів, що продукуються багатьма клітинами, зокрема CD4+ i CD8+ T-клітинами. Важливим $€$ підтримання балансу в імунній відповіді між Th1/Th2-цитокінами. Глюкокортикостероїди відіграють важливу роль у пригніченні IFN-відповіді, діючи безпосередньо на Т-клітини або, опосередковано, через ІЛ-2 та ІЛ-12 [10-12]. За дослідженням [10], підвищення рівня кортизолу буде викликати зниження продуктів Th1 з дисбалансом між Th1/Th2-цитокінами і переходом до відповіді Th2.

ІЛ-2 - це прозапальний цитокін, який стимулює регуляторні Т-клітини, значення яких полягає в контролі запалення. ІЛ-2 індукує проліферацію клітин природних кілерів та посилює їх цитолітичну активність, сприяє виробленню антитіл та їх проліферації В-клітинами, і має важливе значення для активацій- 
но індукованої загибелі клітин, що важливо для гомеостазу та усунення потенційно шкідливих аутореактивних клітин [13]. ІЛ-2 бере участь в імунній відповіді (відіграє важливу роль в імунорегуляторних реакціях) в основному за рахунок утворення CD4 ${ }^{+}$та $\mathrm{CD}^{+}$Т-клітин. За останніми дослідженнями спектр визнаних впливів ІЛ-2 розширився, він сприяє диференціації Th1- та Th2-клітин, при цьому інгібуючи розвиток Th17- [11, 14, 15].

Цікавим $€$ те, що ІЛ-2 може чинити одночасний вплив на регулювання гомеостазу в мозку та в імунній системі [16]. На сьогодні є багато досліджень нейродегенеративних захворювань, де підкреслено роль ІЛ-2 у роботі імунної і центральної нервової систем. Миші із блокуванням дії рецепторів ІЛ-2 демонструють модифрікації цитоархітектурної структури в зубчастій звивині гіпокампа та мають порушення здатності до навчання та пам'яті, що в основному пояснюється імунодефіцитними властивостями ІЛ-2 [13, 15, 17]. Десріцит ІЛ-2 в імунній системі тварин призводить до спонтанного розвитку аутоімунного захворювання, що характеризується інфільтрацією Т-клітин (а в деяких випадках і депонуванням аутоантитіл), що вражає окремі органи та системи $[15,17]$.

За дослідженнями [12, 18], ІЛ-2 разом 3 ІЛ-6, впливають на нервову систему та поведінкову активність тварин. Препарат рекомбінантного ІЛ-2 ефрективно використовується при лікуванні імуносупресії, викликаної стресом, і володіє стимулюючим та антидепресивним ефектами. Тож ІЛ-2 має багатоспрямовану фрізіологічну дію, не тільки сприяючи проліферації Т-клітин та модулюючи ефекторну диференціацію клітин, але й обмежуючи потенційно небезпечні аутоімунні реакції.

Метою дослідження було оцінити вплив ІЛ-2 на рівень кортизолу та динаміку поведінкових реакцій у мишей при фрізичному стресі.

\section{МАТЕРІАЛИ I МЕТОДИ}

Дослідження проводили на білих безпородних статевозрілих лабораторних мишах-самцях із масою (29士3) г, яких утримували в стандартних умовах віварію. У роботі дотримувалися загальних етичних принципів з Європейської конвенції про захист хребетних тварин, що використовуються для експериментів та інших наукових цілей (Страсбург, 2005) та Загальних етичних принципів експериментів на тваринах (Київ, 2013).

Були сорормовані п'ять дослідних та одна контрольна (без фрізичних тренувань) групи тварин. Тварини першої групи отримували інгібітор ІЛ-2 («Сандимун Неорал», «Циклоспорин») перорально по 0,4 мл (концентрація 10 мг/кг). Друга, третя та четверта дослідні групи підшкірно отримували препарат ІЛ-2 («Ронколейкін», ПАТ «Біотех») по 0,2 мл у концентраціях 5000 МО/кг, 7500 МО/кг та 30000
МО/кг відповідно. П'ятій групі тварин вводили стерильний фрізіологічний розчин у еквіоб'ємі. Препарати вводили 3 рази на тиждень, перед кожним тренуванням. Через 4 тижні робили перерву в фрізичних тренуваннях на 14 днів. Дослідження тривало 6 тижнів. Метод примусового плавання до повного виснаження 3 вантажем (7,5 \% від маси тіла) використовували у якості фрізичного тренування. Тварини плавали кожного дня (через 1 годину після введення препаратів) до повного виснаження, яким було опускання на дно або ж 3 безуспішні спроби спливти на поверхню.

Експериментальне дослідження поділили на 3 періоди для визначення стресових змін - 2; 4 та 6 тижнів. Використовували дослідження рівня концентрації кортизолу під час адаптації до фрізичного навантаження для з'ясування пливу інгібування та стимулювання ІЛ-2. Кількісне визначення вмісту кортизолу в сироватці крові здійснювалося за допомогою методу конкурентного імуноферментного аналізу з використанням стандартного набору реагентів «Кортизол - ІФА», згідно з інструкцією виробництва «Гранум». Концентрацію гормону визначали вдень.

Для виявлення індивідуальних розбіжностей характеристик поведінки дослідних груп мишей використовували методику «відкрите поле». Тестування проводили на 1-4-му та 6-му тижнях. Відеофіксацію проводили 5 хв, обробку відеозаписів здійснювали програмою «Realtimer». Під час тесту реєстрували такі показники: горизонтальну (за часом знаходження на периферії та в центрі поля) та вертикальну (за числом вертикальних стійок) рухову активність; «емоційність» та реакції пасивного стресу (за часом завмирання, кількістю дефекацій та часом грумінгу).

Статистичну обрабку даних проводили з використанням критеріїв Манна - Уїтні та Вілкоксона, результат вважали достовірним при $\mathrm{p} \leq 0,05$.

\section{РЕЗУЛЬТАТИ Й ОБГОВОРННЯ}

Кортизол - головний ендогенний глюкокортикоїд, який у людини та гризунів виробляється під час стресових реакцій, а також бере участь у їх регуляції [19]. Відомо, що кортизол може активуватися орізичними, срізіологічними та психологічними стресорами $[2,7]$. Оцінка динаміки концентрації кортизолу при екстремальних впливах є важливим показником розвитку стрес-реакції. Так, при психосоціальному стресі рівень кортизолу, як правило, наростає, що відповідає концепції загального адаптаційного синдрому [1]. Однак при фрізичних навантаженнях, особливо у спортсменів, рівень кортизолу може не змінюватися або ж знижуватися [2, 4, 19]. Факт зниження кортизолу розцінюється як показник недостатньо вираженого стресового впливу, що часто суперечить як силі самого впливу, почуттям пере-
Вісник медичних і біологічних досліджень Bulletin of Medical and Biological Research
$2(8), 2021$ 
вантаження, стомлюваності, так і показникам фрункціональної активності серцево-судинної системи [2, 20]. Тому концентрація кортизолу може використовуватися як маркер розвитку стресу, в тому числі й при фрізичних тренуваннях.

За Суздальницьким [21], в адаптації до фрізичних тренувань виділяють певні етапи, тому в дослідженні динаміку рівня кортизолу досліджували відповідно до цих етапів: 2 тижні (фраза компенсації), 4 тижні (фраза декомпенсації), 6 тижнів (фраза відновлення).

На кожному періоді дослідження проводили кількісне визначення концентрації кортизолу в сироватці крові мишей як показника інтенсивності стресового впливу (рис. 1).

Реакція на експериментальні впливи супроводжувалася закономірним підвищенням концентрації кортизолу, але такі зміни були неоднорідними в різних дослідних групах тварин. Ми відмічали коливання концентрації кортизолу на кожному етапі дослідження, але найбільш показовими вони були у фразі відновлення (наприкінці 6-го тижня), коли, після 4-х тижнів фрізичних тренувань дослідних тварин (плавання з вантажем), робили перерву на 14 днів для перевірки післядії дослідних препаратів.

На 2-му тижні фрізичних тренувань рівень кортизолу в сироватці крові тварин усіх дослідних груп не мав достовірних змін.

Стимуляція ІЛ-2 у високій концентрації призвела до суттєвого збільшення рівня кортизолу в сироватці крові мишей на 4-му та 6-му тижнях порівняно 3 контролем та попереднім періодом $(p \leq 0,05)$. При цьому максимум показника спостерігався на 6-му тижні фрізичних тренувань - підвищення на 267 \%, порівняно 3 контролем, та на 161 \% порівняно 3 попереднім періодом.

Дослідні тварини, яким вводили ІЛ-2 в середній концентрації, мали помірне збільшення рівня кор- тизолу, який зростав протягом усіх фраз адаптації до фрізичного навантаження. Спостерігались достовірні відмінності порівняно з контролем (відповідно, на 51,8 \% - на 4-му тижні, на 36,5 \% - на 6-му тижні, $\mathrm{p} \leq 0,05)$.

У групі тварин з інгібуванням ІЛ-2 рівень кортизолу на 4-му тижні знизився, порівняно з попереднім

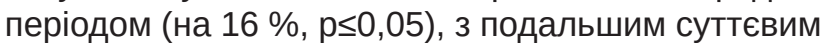
підвищенням наприкінці срізичних тренувань (на $110 \%, p \leq 0,05)$.

Група тварин зі стимулюванням ІЛ-2 в низькій концентрації та група без впливу препаратів продемонстрували підвищення рівня кортизолу порівняно з контролем на 4-му тижні та порівняно з попередніми показниками на 6-му тижні фрізичних тренувань. При цьому протягом усіх періодів дослідження показник рівня кортизолу в групі із введенням ІЛ-2 у низькій концентрації був дещо меншим.

Тож дослідження концентрації кортизолу в сироватці крові мишей при фрізичному тренуванні показало помітний стрес-протекторний ефект рекомбінантного ІЛ-2. Причому цей есрект залежав від концентрації препарату. 3 рисунку 1 видно, що в групі тварин із введенням ІЛ-2 у середній концентрації не було значного підвищення рівня кортизолу. Під впливом малої концентрації ІЛ-2 рівень концентрації кортизолу підвищувався, а потім спостерігався значний спад. У свою чергу, ІЛ-2 у високій концентрації викликав підвищення рівня кортизолу протягом усіх тижнів, із значним стрибком (найвищий показник за експеримент) на 6-му тижні фрізичних тренувань.

Дослідження поведінкової компоненти стресвідповіді є важливим, адже при розвитку адаптаційної реакції стресасоційовані когнітивні процеси та поведінкові реакції набувають вирішального значення для реалізації відповідних адаптивних поведінкових стратегій. За допомогою методики «відкрите

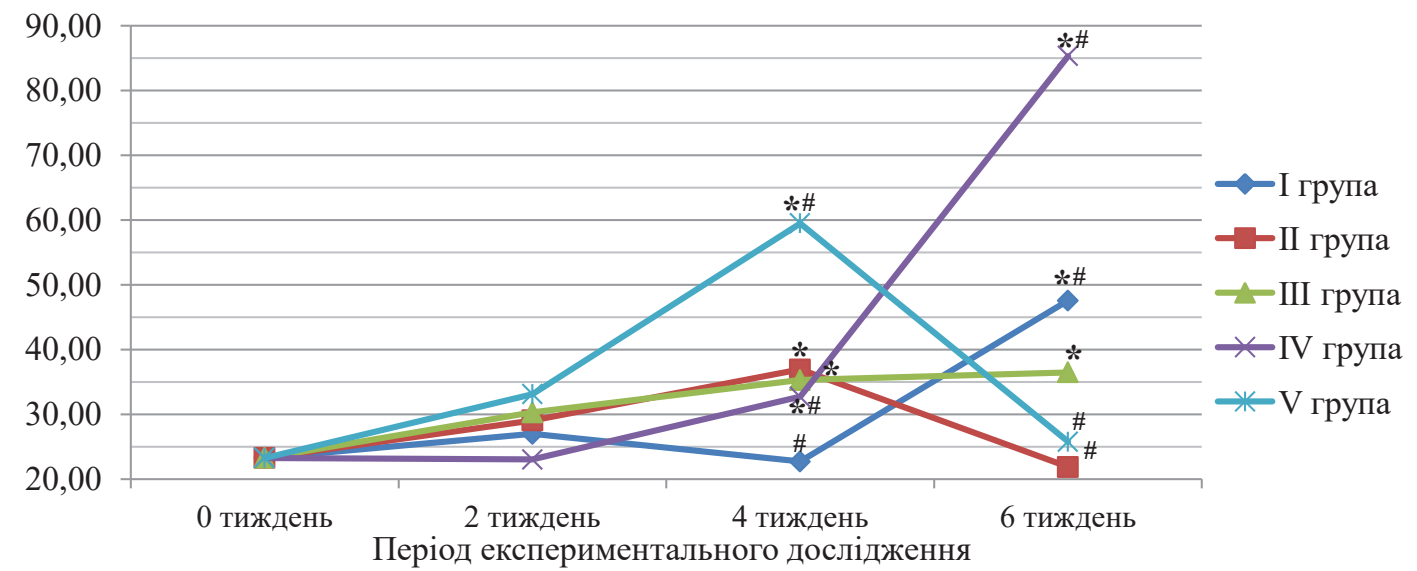

Рис. 1. Динаміка рівня кортизолу.

Примітки: 1) * - достовірні відмінності порівняно з контролем;

2) \# - достовірні відмінності порівняно з попереднім періодом, $p \leq 0,05$. 
поле» ми оцінювали особливості дослідної і емоційної активності тварин та резистентність до стресу за Холом [8]. Динаміка поведінкової активності дослідних груп тварин показана на рисунку 2.

Проаналізувавши динаміку поведінкової активності мишей першої групи було відмічено, що рухова активність у центрі поля знизилась після 2-го тижня, натомість, на периферії поля - підвищилась на 2-му
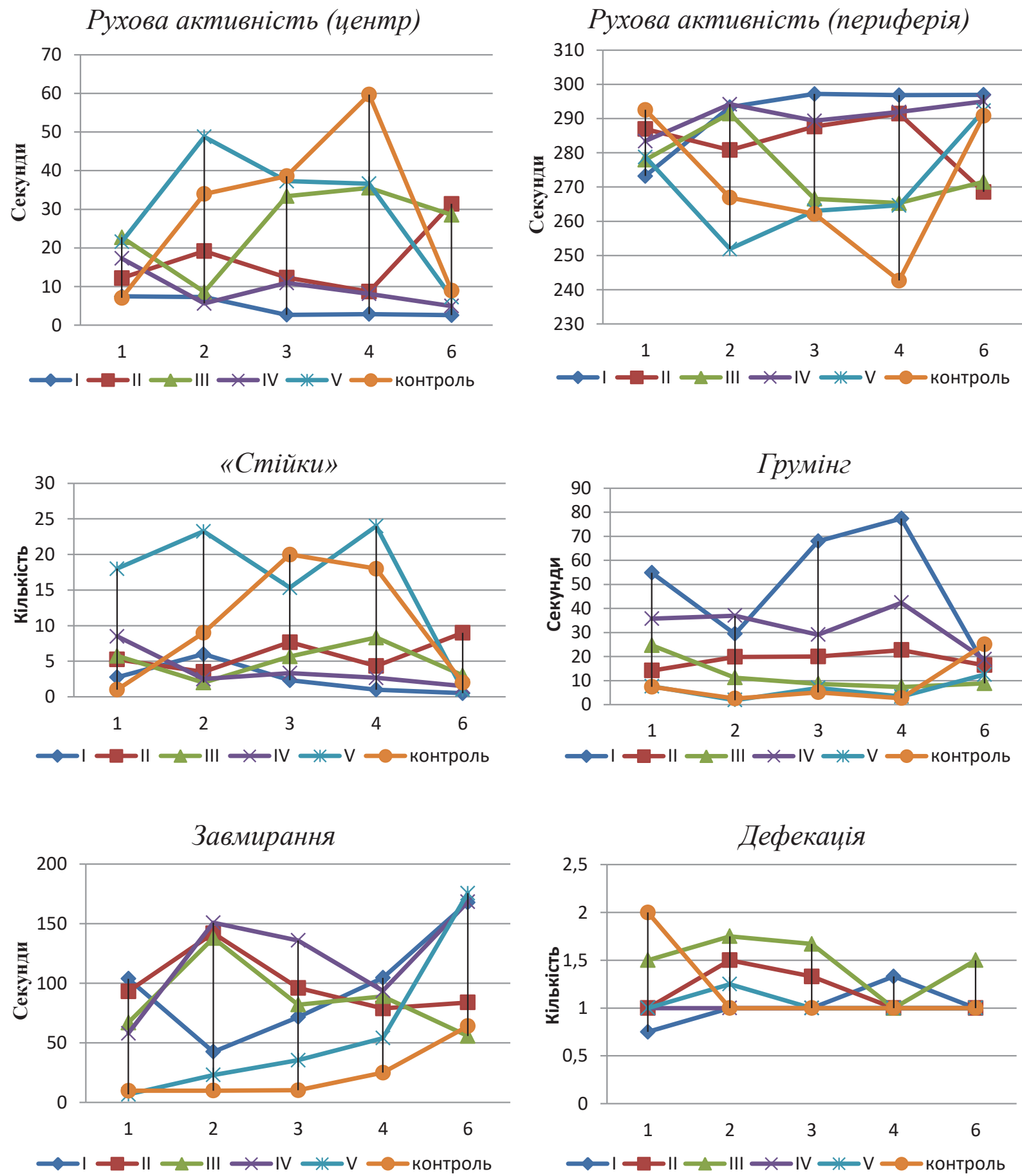

тижні та надалі майже не змінювалась. У свою чергу, кількість стійок підвищилась на 2-му тижні та поступово знижувалась на наступних тижнях.

У тварин другої групи показник часу рухової активності на периорерії поступово зростав протягом експерименту, достовірно знижуючись лише на 6-му тижні. Рухова активність у центрі поля та кількість горизонтальних стійок, навпаки, значно підви-
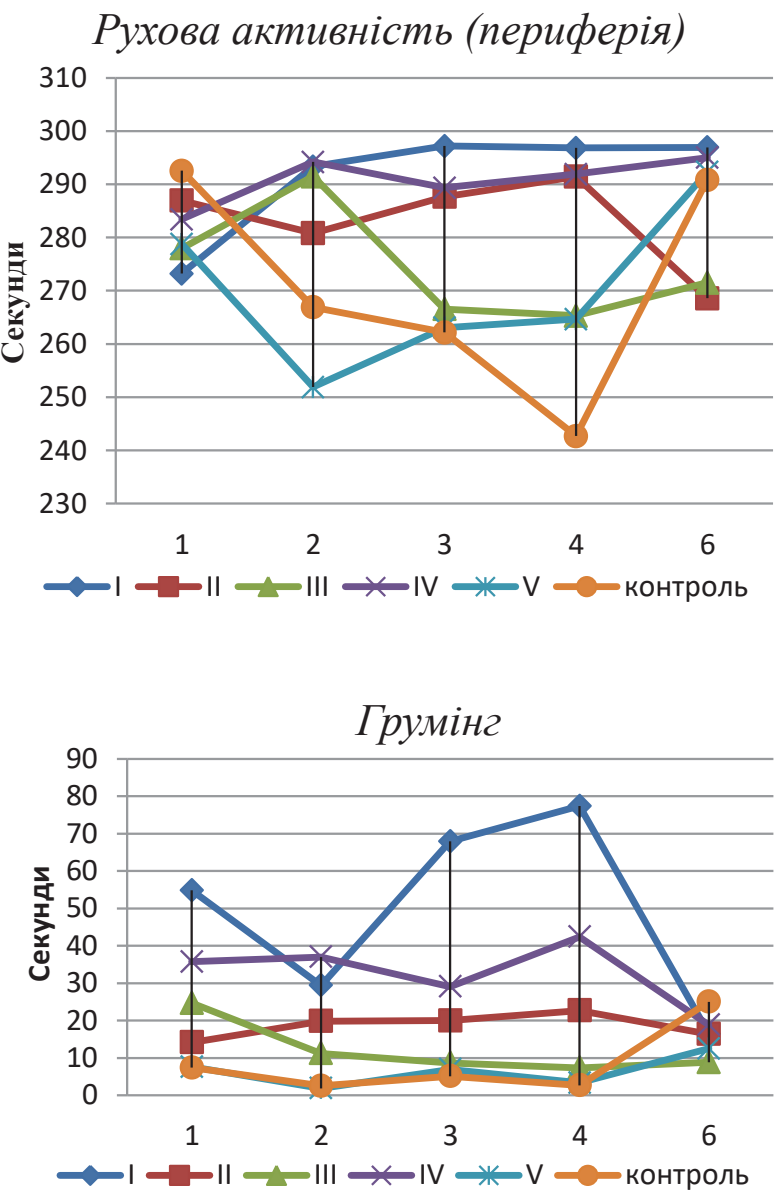

Рис. 2. Динаміка поведінкової активності.

Примітка. 1, 2, 3, 4, 6 - тижні експериментального дослідження. 
щились наприкінці експерименту. Цей фракт можна пояснити звиканням мишей до невеликих доз препарату.

Рухова активність на периферії в третій дослідній групі знизилась на 3-му тижні відносно початкових значень, надалі показник був нижче початкового, натомість, рухова активність в центрі значно знизилась на 2-му тижні та потім достовірно підвищилась на 3-му тижні й залишалась значно вищою вихідних значень. Кількість стійок підвищувалась на 3-му та 4-му тижнях і знижувалась на 2-му та 6-му тижнях дослідження.

Можна відмітити, що рухова активність на периферії в тварин четвертої дослідної групи не зазнала достовірних змін протягом експерименту, а показники рухової активності в центрі та кількість стійок - знизились на 2-му тижні й були надалі нижче початкового значення.

Показники рухової активності п'ятої групи тварин (отримували ін'єкції фрізіологічного розчину), не відрізнялися від аналогічних показників тварин контрольної групи (без фрізичного навантаження). Показники рухової активності на периферії поля знижувались від 2-го до 4-го тижнів та підвищувались наприкінці дослідження, рухова активність навпаки підвищувалась у цей період і зазнавала спаду на 6-му тижні. Кількість стійок в обох групах була високою, але сильно знизилась на 6-му тижні.

Протягом усіх періодів експериментального дослідження була відзначена відмінність показників поведінкової активності в тесті «відкрите поле» залежно від періоду експерименту та впливу ІЛ-2 різної концентрації або ж його інгібування. Так, були виявлені відмінності між дослідними групами в показниках емоційної реактивності та вираженням пасивного страху.

У тварин першої групи показники кількості актів грумінгу, завмирання та дефекацій демонстрували тенденцію до зростання протягом експерименту, що $€$ показником збільшення емоційної реактивності та розвитку реакції страху. У тварин другої групи показники грумінгу незначно коливалися протягом експерименту, час завмирання значно підвищився на 2-му тижні 3 подальшим падінням до вихідного рівня. В третій дослідній групі було відмічено стабілізацію показників грумінгу і завмирання від середини і до кінця експериментального дослідження. В четвертій групі тварин показники грумінгу не мали достовірних відмінностей протягом експерименту, показники ж завмирання суттєво збільшилися до кінця експерименту. Показники часу грумінгу та завмирання у тварин п'ятої та контрольної груп були невисокими з підвищенням наприкінці експерименту. Протягом дослідження не спостерігалось значних змін в кількості актів десрекації тварин усіх дослідних груп.

Отже, попередні дослідження показують, що ІЛ-2 може використовуватись як імунонейроендокринний регулятор фрункції надниркових залоз [7, 12, 13, 18]. Застосування ІЛ-2 має прямий вплив на підвищення концентрації адренокортикотропного гормону в плазмі крові та сироваткового кортизолу [22]. Активація різних нейроендокринних шляхів за певних стресових умов може по-різному впливати на місцеву регуляцію рівня глюкокортикоїдів в органах, що призводить до різноспрямованої динаміки кортизолу та кортикостерону. Показано, що кортизол і кортикостерон сироватки мишей тісно співвідносяться між собою в динаміці розвитку різних фрізіологічних станів або ж у стресових умовах. Кортикостерон вважається біомаркером тісно пов'язаним із адаптацією до хронічного стресу, у свою чергу, кортизол пов'язують із розвитком гострого стресу $[3,19]$.

Ми вважаємо, що підвищення рівня кортизолу на 4-му тижні фрізичних тренувань у другій-п'ятій дослідних групах може бути результатом фрормування резерву глюкокортикоїдів та підвищення резистентності організму до тривалих фрізичних навантажень. У свою чергу, підтримання сталого рівня кортизолу, або ж його зниження наприкінці дослідження (фраза відновлення), може бути підтвердженням активізації гормонального механізму регуляції м'язової діяльності. Відомо, що із збільшенням тренованості підвищується резистентність організму до м'язового навантаження як до стресора. Згідно з літературними даними, в процесі адаптації організму до систематичної м'язової діяльності, можуть наставати перетворення, що супроводжуються зменшенням кількості глюкокортикоїдних рецепторів у цитоплазмі клітин скелетних м'язів, а також зміною чутливості тканин до гормонів [6, 20]. На 6-му тижні фрізичних тренувань у нашому дослідженні відмічено зниження рівня кортизолу в другій та п'ятій дослідних групах та незначне підвищення у третій дослідній групі, що $€$ позитивним показником адаптації до фрізичних тренувань. У свою чергу, в першій та четвертій дослідних групах у цей період концентрація кортизолу значно підвищилась, що може свідчити про недосконалість проходження адаптаційних процесів у тварин цих груп.

\section{ВИСНОВКИ}

3'ясовано, що уведення рекомбінантного ІЛ-2 впливає на концентрацію кортизолу в сироватці крові лабораторних мишей, які знаходились в умовах фрізичних навантажень. У тварин, яким уводили ІЛ-2 в середній концентрації, не було значного підвищення рівня кортизолу. При уведенні малих концентрацій ІЛ-2 рівень кортизолу підвищувався із значним спадом у фразі відновлення. В умовах дії високих концентрацій ІЛ-2 рівень кортизолу підвищувався протягом всіх тижнів, із значним стрибком на останньому тижні фрізичних тренувань. Тож, середні концентрації ІЛ-2 мають стрес-протекторну дію в умовах фрізичних навантажень. 
На моделі фрізичного стресу в білих мишей показано, що уведення рекомбінантного ІЛ-2 впливає на поведінку дослідних тварин. У середніх концен-

\section{СПИСОК ЛІТЕРАТУРИ}

1. Меерсон Ф. З. Адаптация к стрессорным ситуациям и фризическим загрузкам / Ф. З. Меерсон, М. Г. Пшенникова. - М. : Медицина, 1988. - 256 с.

2. Козлов В. А. Иммунная система и сризические нагрузки / В. А. Козлов, О. Т. Кудаева // Медицинская иммунология. - 2002. - Т. 4, № 3. - С. 427-438.

3. Gleeson M. Immune function in sport and exercise / M. Gleeson // J. Appl. Physiol. - 2007. - Vol. 103. - P. 693-699.

4. Nieman D. C. The compelling link between physical activity and the body's defense system/D. C. Nieman, L. M. Wentz // J. Sport Health Sci. - 2019. - Vol. 8 (3). - P. 201-217.

5. Wang J. Exercise regulates the immune system / J. Wang, Sh. Liu, G. Li, J. Xiao // Adv. Exp. Med. Biol. - 2020. - Vol. 1228. - P. 395-408.

6. Effect of acute and chronic aerobic exercise on immunological markers: a systematic review / C. A. M. Gonçalves, P. M. S. Dantas, I. K. D. Santos [et al.] // Front Physiol. -2019. - Vol. 10. - P. 1602.

7. Hackney A. C. Stress and the neuroendocrine system: the role of exercise as a stressor and modifier of stress / A. C. Hackney // Expert Rev. Endocrinol. Metab. - 2006. Vol. 1 (6). - P. 783-792.

8. Буреш Я. Методики и основные эксперименты по изучению мозга и поведения / Я. Буреш, О. Бурешова, Дж. П. Хьюстон. - М. : Высшая школа, 1991. - 527 с.

9. Effect of interleukin-2 on the humoral link of immunity during physical activity / V. Shvets, A. Shkuropat, Y. Prosiannikova, I. Golovchenko // Journal of Physical Education and Sport. - 2020. - Vol. 20 (Supplement issue 6). P. 3153-3159.

10. $\mathrm{T}$ helper $1 / \mathrm{T}$ helper 2 cytokine imbalance in respiratory syncytial virus infection is associated with increased endogenous plasma cortisol / R. A. Pinto, S. M. Arredondo, M. R. Bono [et al.] / Pediatrics. - 2006. Vol. 117 (5): e878-86.

11. Suzuki K. Effect of exercise intensity on cell-mediated immunity / K. Suzuki, H. Harumi // Sports (Basel). - 2021. - Vol. 9 (1). - P. 8.

12. Short- and long-term effects of interleukin-2 treatment on the sensitivity of periadolescent female mice to interleukin-2 and dopamine uptake inhibitor / J. S. Rankin,

\section{REFERENCES}

1. Meerson FZ, Pshennikova MG. Adaptation to stressful situations and physical loads. [Адаптация к стрессорным ситуациям и оризическим загрузкам] Moscow: Meditsina, 1988. Russian.

2. Kozlov VA, Kudaeva OT. [Immune system and exercise]. Meditsinskaya immunologiya. 2002;4(3): 427-38. Russian.

3. Gleeson M. Immune function in sport and exercise. J Appl Physiol. 2007;103: 693-9.

4. Nieman DC, Wentz LM. The compelling link between physical activity and the body's defense system. J Sport Health Sci. 2019;8(3): 201-17. DOI: 10.1016/j. jshs.2018.09.009 траціях ІЛ-2 призводить до зниження рівня тривожності, підвищення рухової активності тварин та активізації їх дослідної поведінки.

S. S. Zalcman, Y. Zhu, A. Siegel // PLoS ONE. - 2013. Vol. 8 (5). - P. e64473.

13. The effects of interleukin-2 on immune response regulation / R. S. Waters, J. S. A. Perry, S. P. Han [et al.] // Math. Med. Biol. - 2018. - Vol. 35 (1) - P. 79-119.

14. Ross S. H. Signaling and function of interleukin-2 in T lymphocytes / S. H. Ross, D. A. Cantrell // Annu. Rev. Immunol. - 2018. - Vol. 36. - P. 411-433.

15. Petitto J. M. Interleukin-2 and the brain: dissecting central versus peripheral contributions using unique mouse models / J. M. Petitto, D. Meola, Z. Huang // Methods Mol. Biol. - 2012. - Vol. 934. - P. 301-311.

16. Klatzmann D. The promise of low-dose interleukin-2 therapy for autoimmune and inflammatory diseases / D. Klatzmann, A. K. Abbas // Nat. Rev. Immunol. - 2015. Vol. 15 (5). - P. 283-294.

17. Interleukin-2 improves amyloid pathology, synaptic failure and memory in Alzheimer's disease mice / S. Alves, G. Churlaud, M. Audrain [et al.] // Brain. - 2017. - Vol. 140 (3). - P. 826-842.

18. Effects of roncoleukin on immune parameters and mixed anxiety/depression state induced by chronic social defeat stress in male mice / A. V. Shurlygina, A. G. Galiamina, E. V. Melnikova [et al.] // Ross. Fiziol. Zh. Im. I.M. Sechenova. - 2014. - Vol. 100 (2). - P. 201-214.

19. Gong S. Dynamics and correlation of serum cortisol and corticosterone under different physiological or stressful conditions in mice / S. Gong, Y.-L. Miao, G.-Z. Jiao [et al.] // PLoSONE. - 2015. - Vol. 10 (2). - P. e0117503.

20. Суздальницкий Р. С. Новые подходы к пониманию спортивных стрессорных иммунодесрицитов / Р. С. Суздальницкий, В. А. Левандо // Теория и практика фриз. культуры. - 2003. - № 1. - C. 18-22.

21. Rutherfurd-Markwick K. Salivary diagnostic markers in males and females during rest and exercise / K. Rutherfurd-Markwick, C. Starck, D. K. Dulson, A. Ali // J. Int. Soc. Sports Nutr. - 2017. -Vol. 14. - P. 27.

22. Interleukin-2 drives cortisol secretion in an age-, dose-, and body composition-dependent way / F. Roelfsema, Y. L. Peter, R. Yang [et al.] // Endocr. Connect. - 2020. Vol. 9 (7). - P. 637-648.

5. Wang J, Liu Sh, Li G, Xiao J. Exercise regulates the immune system. Adv Exp Med Biol. 2020;1228: 395-408. DOI: 10.1007/978-981-15-1792-1 27

6. Gonçalves CAM, Dantas PMS, Santos IKD, Dantas M, da Silva DCP, Tinoco Cabral BrG, et al. Effect of acute and chronic aerobic exercise on immunological markers: a systematic review. Front Physiol. 2019;10: 1602. DOI: 10.3389/fphys.2019.01602

7. Hackney AC. Stress and the neuroendocrine system: the role of exercise as a stressor and modifier of stress. Expert Rev Endocrinol Metab. 2006;1(6): 783-92. DOI: $10.1586 / 17446651.1 .6 .783$ 
8. Buresh Ya, Bureshova O, Khyuston JP. Techniques and basic experiments to study the brain and behavior. [Методики и основные эксперименты по изучению мозга и поведения] Moscow: Vysshaya shkola; 1991. Russian.

9. Shvets V, Shkuropat A, Prosiannikova Y, Golovchenko I. Effect of interleukin-2 on the humoral link of immunity during physical activity. Journal of Physical Education and Sport. 2020;20(Suppl issue 6): 3153-9. DOI: 10.7752/jpes.2020.s6427

10. Pinto RA, Arredondo SM, Bono MR, Gaggero AA, Díaz PV. T helper $1 / T$ helper 2 cytokine imbalance in respiratory syncytial virus infection is associated with increased endogenous plasma cortisol. Pediatrics. 2006;117(5): e878-86. DOI: 10.1542/peds.2005-2119

11. Suzuki K, Harumi H. Effect of exercise intensity on cell-mediated immunity. Sports (Basel). 2021;9(1): 8. DOI: $10.3390 /$ sports9010008

12. Rankin JS, Zalcman SS, Zhu Y, Siegel A. Short- and long-term effects of interleukin-2 treatment on the sensitivity of periadolescent female mice to interleukin-2 and dopamine uptake inhibitor. PLoS ONE. 2013;8(5): e64473. DOI: 10.1371/journal.pone.0064473

13. Waters RS, Perry JSA, Han SP, Bielekova B, Gedeon T. The effects of interleukin-2 on immune response regulation. Math Med Biol. 2018;35(1): 79-119. DOI: 10.1093/imammb/dqw021

14. Ross SH, Cantrell DA. Signaling and function of interleukin-2 in T lymphocytes. Annu Rev Immunol. 2018;36: 411-33. DOI: 10.1146/annurev-immunol-042617-053352

15. Petitto JM, Meola D, Huang Z. Interleukin-2 and the brain: dissecting central versus peripheral contributions using unique mouse models. Methods Mol. Biol. 2012;934: 301-11. DOI: 10.1007/978-1-62703-071-7 15
16. Klatzmann D, Abbas AK. The promise of low-dose interleukin-2 therapy for autoimmune and inflammatory diseases. Nat Rev Immunol. 2015;15(5): 283-94. DOI: $10.1038 /$ nri3823

17. Alves S, Churlaud G, Audrain M, Michaelsen-Preusse K, Fol R, Souchet B, et al. Interleukin-2 improves amyloid pathology, synaptic failure and memory in Alzheimer's disease mice. Brain. 2017;140(3): 826-42. DOI: 10.1093/ brain/aww330

18. Shurlygina AV, Galiamina AG, Melnikova EV, Panteleeva NG, Tenditnik MV, Trufakin VA, et al. Effects of roncoleukin on immune parameters and mixed anxiety/ depression state induced by chronic social defeat stress in male mice. Ross Fiziol Zh Im IM Sechenova. 2014;100(2): 201-14.

19. Gong S., Miao Y-L, Jiao G-Zh, Sun M-J, Li H, Lin J, et al. Dynamics and correlation of serum cortisol and corticosterone under different physiological or stressful conditions in mice. PLoSONE. 2015;10(2): e0117503. DOI: 10.1371/ journal.pone.0117503

20. Rutherfurd-Markwick K, Starck C, Dulson DK, Ali A. Salivary diagnostic markers in males and females during rest and exercise. J Int Soc Sports Nutr. 2017;14: 27. DOI: 10.1186/s12970-017-0185-8

21. Suzdalnitskiy RS, Levando VA. [New approaches to understanding sports stress immunodeficiencies] Teoriya i praktika fiz. kultury. 2003;1: 18-22. Russian.

22. Roelfsema F, Peter YL, Yang R, Takahashi P, Veldhuis JD Interleukin-2 drives cortisol secretion in an age-, dose-, and body composition-dependent way. Endocr Connect. 2020;9(7): 637-48. DOI: 10.1530/EC-20-0211 